\title{
Experience with the Once - Daily Calcium Antagonist Amlodipine on 24 - Hour Ambulatory Blood Pressure in Hypertensive Patients
}

\author{
E. Susalit, R.P. Sidabutar
}

\begin{abstract}
Abstrak
Telah diteliti efektivitas dan tolerabilitas pemberian dosis tunggal antagonis kalsium amlodipin (5-10 mg) pada 20 penderita hipertensi ringan dan sedang. Untuk menilai efek amlodipin, selain dipakai sfigmomanometer air raksajuga dipergunakan alat pengukur tekanan darah 24 jam ambulatoar. Pengukuran tekanan darah secara ambulatoar selama 24 jam setelah pengobatan amlodipin selama 8 minggu, memperlihatkan bahwa obat ini efektif menurunkan tekanan darah selama 24 jam, tanpa merubah pola normal sirkadian.
\end{abstract}

\begin{abstract}
The antihypertensive efficacy and tolerability of once-daily calcium antagonist amlodipine (5-10 mg) were studied in 20 patients with mild to moderate hypertension. 24-hour ambulatory blood pressure monitoring in conjunction with sphygmomanometric measurement were used to study the effects of amlodipine. 24-hour ambulatory blood pressure monitoring made after 8 weeks of treatment with amlodipine revealed that amlodipine effectively reduced blood pressure throughout the whole 24-h period without altering the normal circadian pattern.
\end{abstract}

Keywords : Amlodipine, hypertension, 24-hour ambulatory blood pressure

\section{INTRODUC'TION}

Amlodipine, a structural analog of nifedipine, the first of the 1,4-dihydropyridine calcium antagonists, has been shown to be effective in the treatment of hypertension. ${ }^{1}$ The structure of amlodipine is shown in Fig. $1 .{ }^{2}$ Amlodipine has been shown to have an elimination half-life of $35 \mathrm{~h}$ following a single oral dose and to be readily absorbed following oral administration, with peak plasma levels being achieved $6-12 \mathrm{~h}$ postdose $^{3,4}$ The pharmacokinetic profile of amlodipine allows once daily administration, which has been shown to reduce blood pressure (BP) measured $24 \mathrm{~h}$ postdose. ${ }^{5}$ The effective antihypertensive dose appears to be 5 or $10 \mathrm{mg}$ once daily, with simple one-step dose adjustment required to meet individual patient's requirements. ${ }^{6}$

The purpose of this study was to evaluate the antihypertensive efficacy and tolerability of once-daily amlodipine during normal daily activity using 24-h ambulatory BP monitoring and periodic clinic BP measurements.<smiles>CCOC(=O)C1=C(C)NC(COCCN)=C(C(=O)OCC)C1c1ccccc1Cl</smiles>

Figure 1. The structure of amlodipine

\section{MATERIALS AND METHODS}

Patient selection

Men and women (not of child bearing potential) aged between 21 and 65 years, who had mild to moderate hypertension with supine and standing diastolic BP

Department of Medicine, Faculty of Medicine, University of Indonesia/Dr. Cipto Mangunkusumo Hospital, Jakarta, Indonesia 
(DBP) of $95-115 \mathrm{~mm} \mathrm{Hg}$ after a minimum of 2 weeks with no therapy were entered into the study.

Patients with malignant or accelerated hypertension, and/or any other severe concomitant pathologic condition were excluded from the study.

The patients were informed of the nature and purpose of the study and were asked to give their consent to participate.

\section{Study design}

A 2-week placebo run-in period was followed by 8 weeks of active treatment with 5-10 mg of amlodipine in a single-blind fashion.

Patients visited the clinic at 2 -week intervals. Standing and supine pulse rate and BP were measured in triplicate at each visit. Hematologic and biochemical tests were carried out at the end of the placebo run-in phase, and after 8 weeks of treatment with amlodipine. A 12-lead electrocardiogram (ECG) was obtained on entry to the study and at the end of the treatment with amlodipine.

At the end of the placebo run-in phase and the treatment with amlodipine, ambulatory BP was measured for 24-h period using an automated, noninvasive device (90207 ABP Monitor, Space Labs Inc., Houston, TX, U.S.A.).
A two-tailed t test was used to compare the mean baseline final changes in clinic $\mathrm{BP}$, daytime and nightime 24-h ambulatory BP, heart rate, and ECG parameters. Statistical significance was calculated at $5 \%$ level.

\section{RESULTS AND DISCUSSION}

\section{Patients}

Twenty patients ( 14 men, 6 women) with a mean age of 47 years (range of 29 to 64 years) were entered into the study.

Three patients failed to fulfill the BP criteria at the end of the placebo phase and were withdrawn. One patient failed to finish the study, because he had to move to another city and so was excluded from the analysis.

Of the remaining 16 patients, seven patients had not received any previous therapy, three patients had received diuretics only, three patients had received beta-blocker, and three patients had received ace-inhibitor. Those drugs were withdrawn before the study.

Eleven patients required an increase in dose to 10 $\mathrm{mg}$ of amlodipine once daily and five remained on 5 $\mathrm{mg}$ daily.

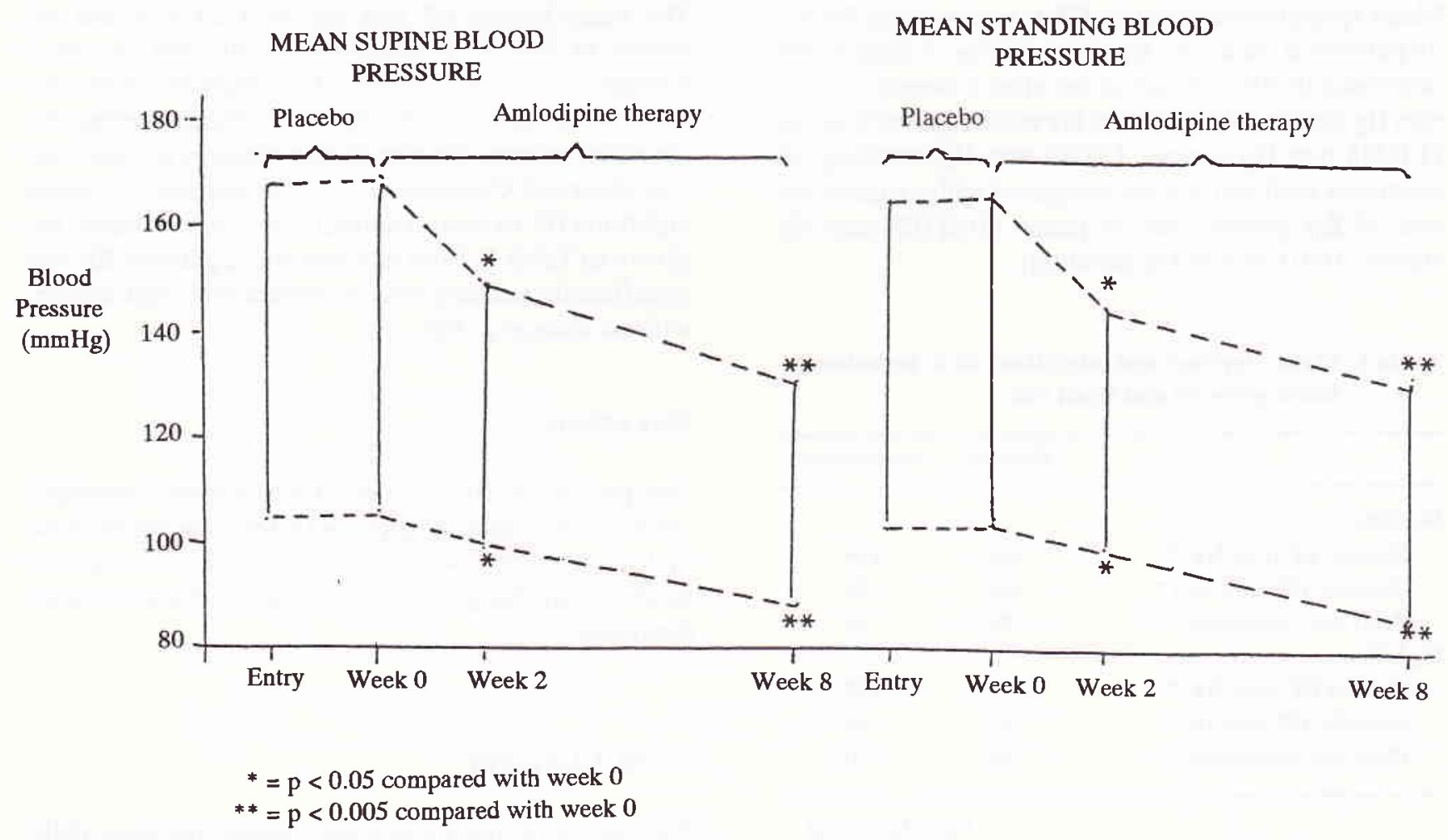

Figure 2. Mean sphygmomanometric blood pressure 


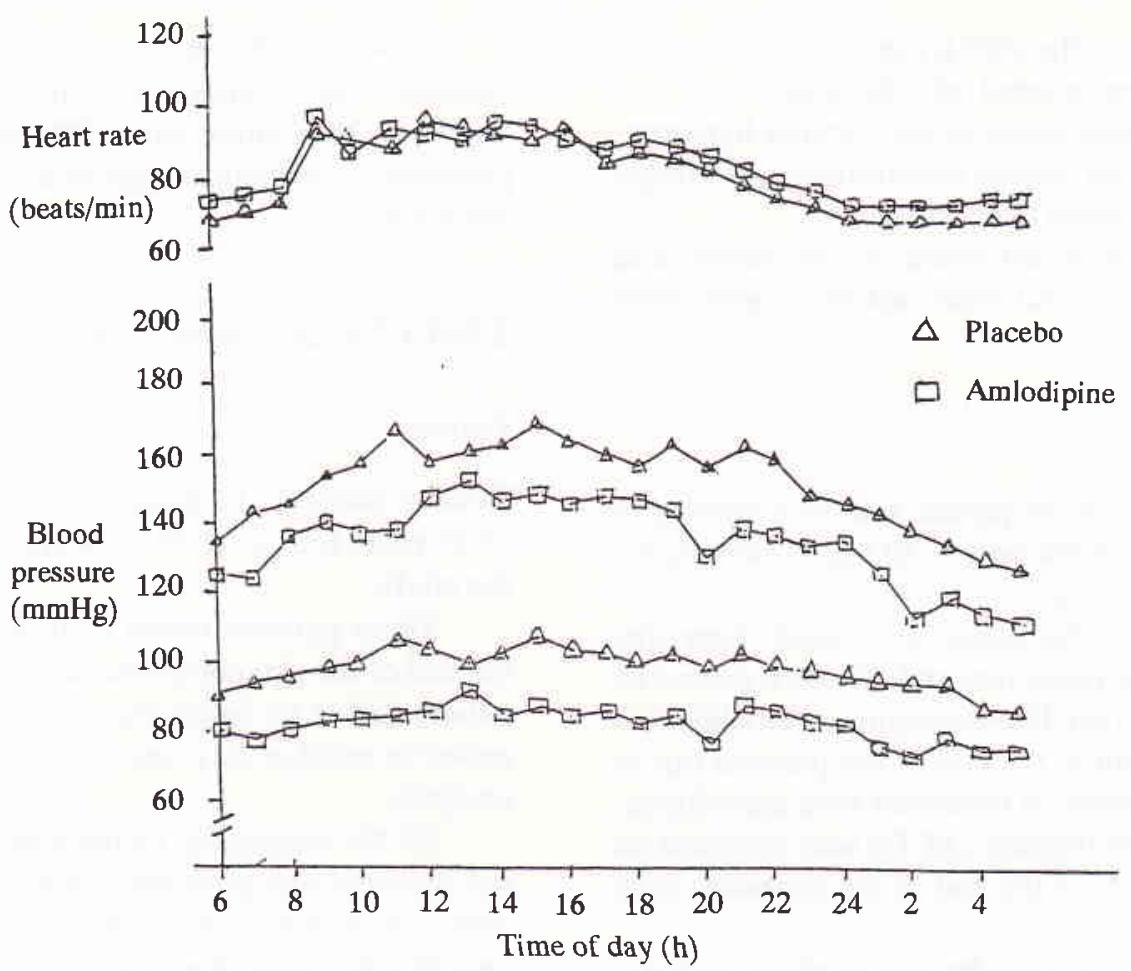

Figure 3. Mean blood pressure and heart rate over a $24-h$ period using ambulatory monitoring

\section{Sphygmomanometric BP}

Mean sphygmomanometric BP measurements for the 16 patients at each visit are shown in Fig. 2. Significant decreases in BP were achieved after 2 weeks (148/96 $\mathrm{mm} \mathrm{Hg}$ supine, 146/97 $\mathrm{mmm} \mathrm{Hg}$ standing) and 8 weeks (133/88 $\mathrm{mm} \mathrm{Hg}$ supine, $133 / 89 \mathrm{~mm} \mathrm{Hg}$ standing) of treatment with amlodipine compared with values at the end of the placebo run-in phase $(166 / 105 \mathrm{~mm} \mathrm{Hg}$ supine, 164/106 mm Hg standing).

Table 1. Mean daytime and nighttime 24-h ambulatory blood pressure and heart rate.

\begin{tabular}{|c|c|c|}
\hline & Placebo & Amlodipine \\
\hline \multicolumn{3}{|l|}{ Daytime } \\
\hline Systolic BP (mm Hg) * & 160 & 139 \\
\hline Diastolic BP $(\mathrm{mm} \mathrm{Hg})$ * & 101 & 89 \\
\hline Heart rate (beats/min) ** & 88 & 89 \\
\hline \multicolumn{3}{|l|}{ Nighttime } \\
\hline Systolic BP (mm Hg) * & 154 & 135 \\
\hline Diastolic BP $(\mathrm{mm} \mathrm{Hg})$ * & 97 & 84 \\
\hline Heart rate (beats $/ \mathrm{min})$ ** & 68 & 70 \\
\hline
\end{tabular}

\section{4-h ambulatory BP}

The mean hourly BP and HR over 24 -h period are shown in Fig. 3. A reduction in BP was observed throughout the 24 -h period after treatment with amlodipine compared with placebo without altering the circadian pattern. No significant changes in heart rate was observed. Comparison of mean daytime and mean nighttime BP values on amlodipine and on placebo are shown in Table 1. Both daytime and nighttime BP was significantly reduced after treatment with amlodipine, with no change in $\mathrm{HR}$.

\section{Side effects}

One patient on $10 \mathrm{mg}$ dose of amlodipine developed ankle edema which disappeared after reducing the dose up to $5 \mathrm{mg}$. There were no significant hematologic or biochemical changes and no changes in the electrocardiograms.

\section{CONCLUSIONS}

The results of this study clearly show that once daily amlodipine provides $24-\mathrm{h}$ BP control without altering 
the physiologic circadian pattern of BP variation. Amlodipine was well tolerated in this study.

\section{REFERENCES}

1. Webster J, Robb OJ, Jeffers A, Scott AK, Petrie JC, Towler $\mathrm{HM}$. Once daily amlodipine in the treatment of mild to moderate hypertension. Br J Clin Pharmacol 1987;27:713-9.

2. Abernethy DR. Amlodipine: Pharmacokinetic profile of a low clearance calcium antagonist. J Cardiovasc Pharmacol 1991;17 (suppl 1):\$4-7.
3. Faulkner JD, McGibney D, Chasseaud LF, Perry JL, Taylor IW. The pharmacokinetics of amlodipine in healthy volunteers after single intravenous and oral doses and after 14 repeated oral doses given once daily. $\mathrm{Br} \mathrm{J}$ Clin Pharmacol 1986;22:21-5.

4. Williams DM, Cubeddu LX. Amlodipine pharmacokinetics in healthy volunteers. J Clin Pharmacol 1988;28:990-4.

5. Frick MH, McGibney D, Tyler HM. Amlodipine : A doubleblind evaluation of the dose-response relationship in mild to moderate hypertension. J Cardiovasc Pharmacol 1988; 12(suppl 7) : S76-9.

6. Julius S. Amlodipine in hypertension: an overview of the clinical dossier. J Cardiovasc Pharmacol 1988;12(suppl 7) : S27-34. 